to the same form as the mandible, and shows that the latter cannot be referred to Machimosaurus.

After reviewing the whole of the evidence, the author concluded that he was dealing with a Crocodilian allied to Metriorhynchus, but forming the type of a new genus, to which he gave the name of Suchodus, adding the specific name of durobrivensis.

4. "On two new Species of Labyrinthodonts." By R. Lydekker, Esq., B.A., F.G.S., etc.

The right ramus of the lower jaw of a Labyrinthodont, from the Lower Carboniferous of Gilmerton, near Edinburgh, is regarded as referable to the Permian genus Macromerum, and it is proposed to describe it as $\boldsymbol{M}$. scoticum.

Another mandible from the Karoo system of South Africa is referred to the American Permian genus Eryops under the name of $E$. Oweni.

\title{
CORRFSPONDEIJCE.
}

\section{THE CRYSTALLINE SCHISTS OF THE LEPONTINE ALPS,}

Sir,-To the abstract of my paper on "The Crystalline Schists and their Relation to the Mesozoic Rocks in the Lepontine Alps," read before the Geological Society on January 22nd, and reprinted in the last Number of this Magazine, has been appended a long letter written by Dr. Heim in anticipatory criticism, which was read during the discussion. As the printing of that letter in extenso appears to me to be a feature even more novel in your MAGazine than it is in the Abstracts of the Geological Society, I request space for the following remarks :-

1. I must leave to casuists more experienced than myself the task of reconciling certain parts of that letter (as to what has been said by Swiss geologists) with the paper, presented by Dr. Heim to the International Geological Congress in 1888. After comparing them, I can only put the old question, "What then does Dr. Heim mean?"

2. The Carboniferous rocks of the Alps were only incidentally mentioned in my paper. But I know something of these also, and shall be surprised if it can be proved that any sedimentary rocks of this age have been converted into true crystalline schists, or that the "Calamite-like trunk from Guttanen" (which I have seen) occurs in a gneiss.

3. In regard to the "crystalline schistose rocks" of Mesozoic age, in which it is stated that Belemnites occur with staurolites, garnets, etc.,- - rocks which are now said not to be true crystalline schists-I have only to remark that the whole aim of my paper was to show that the rocks with garnet, staurolite, etc., were true crystalline schists, that they were totally distinct from the schistose rocks with fossils, that the former were below not above the (Triassic) rauchwacke, in which some of their members actually occur as fragments, that the Belemnite-bearing rucks have only a superficial 
resemblance to the schists with garnet and staurolite, and that the authigenous minerals in them are neither garnet nor staurolite, but some impure hydrons silicates. Dr. Heim's letter merely asserts the contrary to my contentions, without adducing any fresh evidence.

T. G. BONNEY.

THE CULM-MEASURES AT BUDE, NORTH CORNWALL.

SIR,-I have read with much interest the paper by Major-General MeMahon on the rocks at Bude. During one of two summer visits to Tintagel I made a short stay at Bude, and saw the extremely contorted strata so well described in the paper referred to. Like the author of that paper, I was desirous of seeing what amount of metamorphism had resulted from so much pressure and dislocation, but expecting to pay a longer visit I took away only two specimens. These were taken from two layers, a few inches apart, of a very sharp fold exposed in a cove a little way south of Bude Haven,-I think it was "Efford Ditch." One of the layers was darker in colour, much softer, and more laminated than the other.

If any conclusions may be drawn from so limited a stock of material (and macroscopically, at least, my specimens appeared fairly representative of many of the rocks in this and other cliffs of the district), the rocks of Bude are entitled to complain that they have been made to appear as being less appreciative of, and as making less return for, the large amount of force expended on them than is really the case.

The microscope shows the general structure and composition of my specimens to be exactly as described by Major-General McMahon; but a close study of very thin portions of slides, under high powers, shows a good deal more, especially in the harder of the two layers.

In among the unaltered original clastic material may be seen a considerable amount of rutile; perfectly distinct from any bits of that mineral which may have come from older rocks. There are large numbers of acicular crystals of it, vividly polarizing, as well as countless minute dark rods, so well shown in many slates, etc. It is also present in grains and granular aggregates, and in plates, some of them of relatively large size. The total amount of it varies much, even in slides from the same small piece, but it is always considerable, and in one slide from the harder layer of rock it is particularly abundant. This slide also shows a good many long crystals of tourmaline (quite distinct from the clastic grains of that mineral) and a good deal of secondary sericitic mica, some of it rich in rutile crystals. Incieed, parts of this slide at once remind one of some of the sericite-phyllites of the Tintagel rocks, in which the rutile occurs in just the same manner; and comparisons of the two leave little doubt that some at least of the Bude strata have made a good start towards the metamorphism which is so intense at Tintagel.

Of course it may be that my two specimens are exceptional, and that Major-General McMahon did not chance on these or similar layers. 